\title{
Kamaz Engine (R6 Series) Reliability Provision
}

\author{
Eduard Mukhamatzakievch Mukhametdinov ${ }^{1}$, Irina Viktorovna Makarova ${ }^{1}$, Larisa Mukhamatzakiyevna Gabsalikhova1, \\ Kapitonov Aleksandr Aleksandrovich ${ }^{2}$, Hafizullin Ilnaz Shaukatovich ${ }^{2}$
}

${ }^{1}$ Ph.D., Associate Professor, Automotive Department, Naberezhnye Chelny Institute, KFU, Id scopus 56941836500, ORCID: 0000-0003-0824-0001, Kazan Federal University

${ }^{2}$ Doctor of Engineering, Professor, Automotive Department, Naberezhnye Chelny Institute, KFU, Id scopus 8901834700, ORCID: 0000-0002-6184-9900, Kazan Federal University

${ }^{3}$ Ph.D. in Engineering, Associate Professor, Automotive Department, Naberezhnye Chelny Institute, KFU, Kazan Federal University, Russia. Id scopus 57188691766, ORCID: 0000-0003-3325-3285

${ }^{4}$ Head of the Design and Technology Department of Product Design and Technology Quality, PJSC "KAMAZ", Id scopus, ORCID: 0000-0002-7665-2510, PAO «KAMAZ»

${ }^{5}$ Design engineer of the 2 nd category at PJSC "KAMAZ", Id scopus,

ORCID: 0000-0002-8302-2410, PAO «KAMAZ»

\begin{abstract}
Quite a few studies have been devoted to the issues of engine reliability increase, and they remain relevant today. During the design stage, it is necessary to analyze as much as possible the parameters that affect the reliability of the engine. The work is devoted to the analysis of the KAMAZ R6 engine reliability, the compliance with the declared resource and the maintenance interval. The analysis of engine reliability, the prediction of its condition is especially important at the design stage to determine the wear rate and the resource of parts, as well as during operation to determine the frequency of maintenance and repair. The engine was tested for its reliability, and based on the data obtained by the extrapolation method, the prediction of the operating time to the limit state was performed. According to the data obtained during the tests, it can be assumed that, subject to the technical recommendations for operation, the declared engine resource of 1,500 thousand $\mathrm{km}$ will be ensured, and in terms of the indicator, the change in oil viscosity will not reach its limit values during the maintenance interval of 120 thousand $\mathrm{km}$. Analytical dependences are derived and the parameters of these dependences are determined - the change of oil waste and crankcase gas consumption.
\end{abstract}

Keywords: reliability, engine, fail-safety, oil viscosity

\section{INTRODUCTION}

The development of the automotive industry is associated with automobile engine design improvement to increase their reliability, efficiency and environmental friendliness. The most worn out parts in an internal combustion engine are cylinders and piston rings, bearings and crankshaft journals. Critical wear of parts can lead to the failure of an internal combustion engine, which will entail costly, time-consuming repairs and the vehicle fleet downtime.

The study of the methods predicting and diagnosing the state of an engine are the most important issues, the solutions of which directly contribute to maintaining the engine in working condition. Correct prediction of engine part wear helps to create the most optimal maintenance and repair schedule, which leads to the reduction of vehicle fleet downtime. Advanced diagnostic methods enable a more accurate diagnosis of the engine, while reducing the time spent on engine repairs, reducing the complexity of the work performed and the likelihood of critical wear.

In this regard, the feasibility of studying the methods for engine state prediction, assigning optimal maintenance intervals to maintain the engine performance increases. Such measures are most important during the design stage of a new internal combustion engine in order to study and improve the design, describe possible breakdowns, and give forecasts for resources and operation. It is important to form the diagnostic parameters of the engine and show their correlation with the actual wear of the components and systems.

\section{METHODS}

A characteristic feature of scientific research in the field of car reliability improvement over the past ten years is that the authors do not consider the reliability of the entire system as a whole, but establish the dependence of individual components and assembly reliability on operating conditions and operating modes. The article [1] compared the methods for prediction the reliability of electronic components. The work [2] substantiates the possibility of truck reliability increase by creating an intelligent system and a method for diagnosing the clutch by monitoring the changes in the vibration level during operation. The method of monitoring the operation of machines using an on-board self-diagnosis system is the most promising trend in a diagnostic system development, which makes it possible to reduce the number of failures, as well as to increase the reliability of trucks. The work [3] analyzes the problems of the braking system reliability using FTA and FMEA analysis. FMEA analysis is one of the widely used methods to assess the system reliability. In the work, when they perform failure 
International Journal of Engineering Research and Technology. ISSN 0974-3154, Volume 13, Number 11 (2020), pp. 3746-3750

(C) International Research Publication House. https://dx.doi.org/10.37624/IJERT/13.11.2020.3746-3750

analysis [4], the FMEA method based on fuzzy logic was used. In [5], the reliability results were compared with the results of repair cost analysis. On this basis, they estimated the failure rates of the components involved. In accordance with the reliability problems of hydropneumatic suspension, the method of combining failure mode and effects analysis (FMEA) and failure tree analysis (FTA) [6] is proposed for combining and system reliability analysis.

Reliability depends on many factors that are different at each stage of an automotive technology life cycle. During the operation stage, the technical condition of the vehicle is analyzed during the warranty period of operation. The analysis of work improving the reliability of the car showed that the largest number of failures of all car systems happens due the internal combustion engine. The analysis of automobile engine reliability was considered in the articles [7], [8], [9].

The main areas of work improving the reliability of engines are the following ones: design improvement by modern material use; improvement of cooling and lubrication systems; the methods for fuel equipment adjustment, analyzing the influence of operating modes and climatic features on engine reliability, finding new ways and solutions for diagnosing the entire engine and its individual units.

The article [10] presents possible applications of acoustic diagnostics during the technical condition check of an internal combustion engine. The study of the methods for prediction and diagnosing an engine state are the most important issues, the solutions of which directly contribute to maintaining an engine in working condition. Bench tests of engines cannot take into account all real operating conditions; they are carried out in order to assess the effectiveness of the proposed structural and technological methods of reliability provision.

\section{RESULTS AND DISCUSSION}

The tests to check the reliability of KAMAZ (P6 series) diesel engine are carried out in order to monitor the quality of products periodically, confirm the possibility of continuing the manufacture of engines according to the current documentation, to monitor the compliance of the main parameters with technical specifications (TS) for engines, to assess the reliability of the engine, and to assess the wear resistance of the main engine parts.

During the tests, the following main works are carried out:

- engine selection;

- checking the engine assembly completeness and quality;

- disassembly of the engine and micrometry of the main parts;

- checking engine units for compliance with regulatory and design documentation (DD);

- engine assembly;

- engine running-in;

- checking the main parameters and adjustments of the engine;

- 50 hour running in;

- determination of control characteristics;

- tests of the engine at failure-free modes;

- determination of the engine control characteristics after the tests in failure-free modes;

- disassembly of the engine, micrometry of the main parts and check of the engine units

- assessment of the wear values of the main engine parts.

The engine is considered to have failed the reliability test:

- in the presence of failures, the elimination of which requires disassembling the engine with the removal of the high pressure fuel pump, cylinder heads, oil crankcase, flywheel, and flywheel housing;

- when knocks appear that are dangerous for the further operation of the engine;

- if, after the end of the tests, the engine cannot continue operation in any modes without part replacement;

- with power decrease or efficiency deterioration during the test by more than $5 \%$;

- when oil consumption exceeds the maximum value specified in the technical specifications for engines;

- when the oil pressure drops below the minimum value set by the technical specifications for engines;

- with wear of the parts exceeding the established values (to be specified according to the results of acceptance tests and periodic tests);

- with pressure and flow rate of crankcase gas increase during the test by more than $5 \%$;

- in case of an engine non-compliance before and after the tests with the requirements of the UNECE Regulation No. 24-03 [11] and the UNECE Regulation No. 49-05B2 (G) [12].

During reliability tests, they determined the data on oil consumption for waste at a certain moment. The data on consumption during 3000 hours of testing (table 1) are optimal for extrapolation due to the largest operating time and a large number of measurements. Moreover, oil consumption for waste is determined as a percentage of fuel consumption $(\mathrm{Q}, \%)$.

Table 1: Oil consumption per carbon monoxide as a percentage of fuel consumption during 3000 test hours

\begin{tabular}{|c|c|c|c|c|c|c|c|c|c|c|c|c|c|c|}
\hline $\mathrm{t}, * 10^{3}$ hour & 0 & 0,05 & 0,45 & 0,75 & 1 & 1,15 & 1,65 & 1,85 & 2,15 & 2,3 & 2,6 & 2,75 & 2,95 & 3 \\
\hline $\mathrm{Q}, \%$ & 0,36 & 0,04 & 0,031 & 0,025 & 0,36 & 0,023 & 0,024 & 0,027 & 0,022 & 0,02 & 0,027 & 0,04 & 0,036 & 0,046 \\
\hline
\end{tabular}




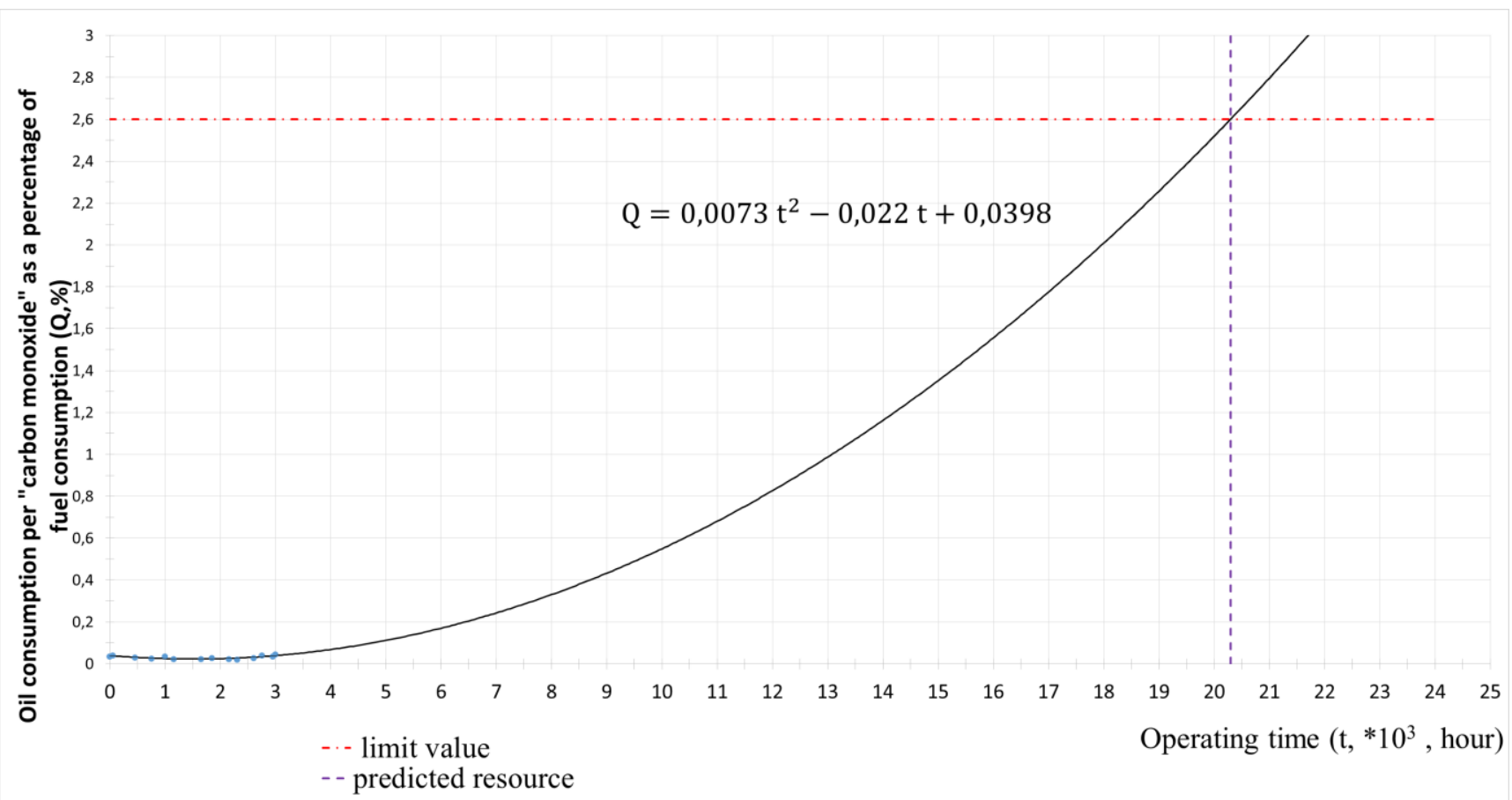

Fig. 1: Determination of predicted engine life by dependence of change in oil flow rate per carbon monoxide

Based on the data of the Table 1, a graph was built (Figure 1), and the analytical dependence was chosen:

$\mathrm{Q}=a \mathrm{t}^{2}-\mathrm{bt}+\mathrm{c}$

They determined the value of the parameters $\mathrm{a}=0.0073, \mathrm{~b}=$ $0.022, \mathrm{c}=0.0398$.

They obtained analytical functions and built a dependence curve:

$Q=0,0073 t^{2}-0,022 t+0,0398$

By extending the series of data determined from the above determined relationship, we found the intersection point with the limit value of oil consumption for waste.

The predicted engine resource was $20.3 * 10^{3} \mathrm{~h}$, which conditionally corresponds to 1421 thousand $\mathrm{km}$, which in turn is almost equal to the declared engine resource of 1500 thousand $\mathrm{km}$.

Diesel oil parameters such as viscosity, density and base number are decreased during operation. The maximum allowable change in viscosity from the initial value is $20 \%$.

During the reliability tests, the change in oil viscosity was monitored. The data on the change in oil viscosity during 1500 h, $2200 \mathrm{~h}, 3000 \mathrm{~h}$ (at $2200 \mathrm{~h}$ the engine oil was replaced) tests (Table 2) is optimal for extrapolation, due to sufficient operating time for analysis, and during these tests the defects that could affect the oil viscosity did not occur. Oil viscosity change data is presented as a percentage of the original viscosity data $(\mathrm{n}, \%)$.
Table 2: Change in oil viscosity relative to initial test values

\begin{tabular}{|c|c|c|c|}
\hline t, $* 10^{3}$ hour & $\begin{array}{c}n_{1}, \% \\
\text { (at } 1000 \\
\text { hours) }\end{array}$ & $\begin{array}{c}\mathrm{n}_{2}, \% \\
\text { (at } 2200 \\
\text { hours) }\end{array}$ & $\begin{array}{c}\text { n3, }_{3} \\
\text { (at } 3000 \\
\text { hours) }\end{array}$ \\
\hline 0 & 0 & 0 & 0 \\
\hline 0,05 & 3,81 & 4,06 & 2,6 \\
\hline 0,2 & 5,33 & 9,18 & 5,52 \\
\hline 0,4 & 7,11 & - & - \\
\hline 0,45 & - & - & 8,4 \\
\hline 0,65 & 7,8 & 10,48 & - \\
\hline 0,8 & 7,54 & - & - \\
\hline 0,9 & - & - & 6,17 \\
\hline 1 & 8,05 & 7,64 & - \\
\hline 1,2 & 7,2 & - & - \\
\hline 1,3 & - & - & 4,63 \\
\hline 1,35 & 6,86 & - & - \\
\hline 1,45 & & 7,88 & - \\
\hline 1,5 & 7,54 & - & - \\
\hline \multirow[t]{2}{*}{1,6} & - & - & 5,2 \\
\hline & - & - & 4,55 \\
\hline 2 & - & 7,4 & - \\
\hline 2,15 & - & - & 5 \\
\hline 2,2 & - & 7,64 & - \\
\hline
\end{tabular}




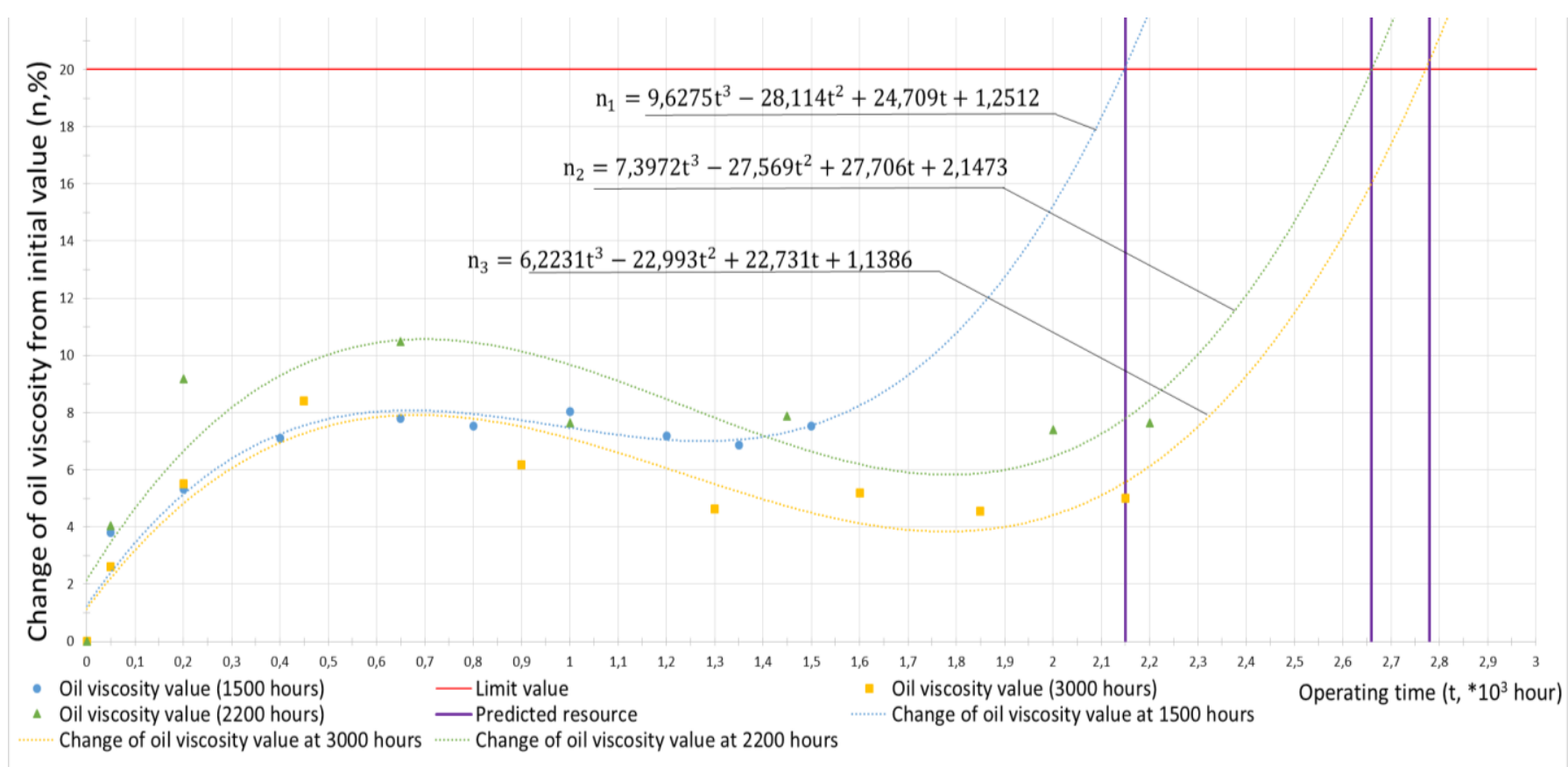

Fig 2: Change of oil viscosity during tests

Based on the data in Table 2, the graph was built (Figure 2), and the analytical dependence was chosen:

$n=a \mathrm{t}^{3}-b \mathrm{t}^{2}+\mathrm{ct}+\mathrm{d}$

They determined the values of the parameters $\mathrm{a}, \mathrm{b}, \mathrm{c}, \mathrm{d}$.

For $1500 \mathrm{~h}$ : a=9,6275, b=28,114, c=24,709, d=1,2512.

For $2200 \mathrm{~h}: \mathrm{a}=7,3972, \mathrm{~b}=27,569, \mathrm{c}=27,706, \mathrm{~d}=2,1473$.

For $3000 \mathrm{~h}: \mathrm{a}=6,2231, \mathrm{~b}=22,993, \mathrm{c}=22,731, \mathrm{~d}=1,1386$.

They obtained analytical functions and developed the dependence curves:

$\mathrm{n}_{1}=9,6275 \mathrm{t}^{3}-28,114 \mathrm{t}^{2}+24,709 \mathrm{t}+1,2512$

$\mathrm{n}_{2}=7,3972 \mathrm{t}^{3}-27,569 \mathrm{t}^{2}+27,706 \mathrm{t}+2,1473$

$\mathrm{n}_{3}=6,2231 \mathrm{t}^{3}-22,993 \mathrm{t}^{2}+22,731 \mathrm{t}+1,1386$

By extending the series of the data determined from the above derived dependencies, we found the intersection points with the limiting value of oil viscosity change from the initial values (Figure 2).

Reaching the boundary value of viscosity during 1500 hours of testing $-2.15 * 10^{3}$ hours $(150.5$ thousand $\mathrm{km})$, during 2200 hours $-2.66 * 10^{3}$ hours (186.2 thousand $\mathrm{km}$ ), during 3000 hours $-2.78 * 10^{3} \mathrm{~h}(194.6$ thousand $\mathrm{km})$.

The declared maintenance interval for the engine is 120 thousand $\mathrm{km}$. It can be concluded that the change in oil viscosity will not reach the limit values during the service interval.

According to the data obtained during the tests, it can be assumed that, subject to the technical recommendations for operation, the declared engine resource of 1500 thousand $\mathrm{km}$ will be ensured, and in terms of the indicator, the change in oil viscosity will not reach its limit values during the maintenance interval of 120 thousand $\mathrm{km}$.

\section{SUMMARY}

By the method of oil waste data extrapolation, the predicted engine resource was obtained and made $20.3 * 10^{3}$ hours, which is conventionally equal to 1421 thousand $\mathrm{km}$, the declared engine resource is 1500 thousand $\mathrm{km}$. Subject to the technical recommendations for operation, the declared resource will be provided. The data on the consumption of crankcase gases confirmed that the wear of the cylinder-piston group is not significant. Analytical dependences are derived and the parameters of these dependences are determined: the change in oil waste consumption $\left(\mathrm{Q}=a \mathrm{t}^{2}-\mathrm{bt}+\mathrm{c}\right)$ and the consumption of crankcase gases $\left(Q_{\mathrm{K}}=a \mathrm{t}+b\right)$. A premium segment oil was used during the tests.

\section{CONCLUSIONS}

Despite the fact that there are structural and technological methods ensuring the reliability of engines, and the results of calculations and engineering analysis are verified experimentally, there is no way to reproduce all the combinations of external factors that may arise in real operating conditions. The analysis of engine reliability, the prediction of its condition is especially important during the design stage to determine the wear rate and resource of parts, as well as in operation to determine the frequency of maintenance and repair. In the conditions of wall tests, it is impossible to take into account all the operational factors correctly. These factors will be taken into account during further research. 


\section{ACKNOWLEDGEMENTS}

The work is performed according to the Russian Government Program of Competitive Growth of Kazan Federal University.

\section{REFERENCES}

[1] A. Thaduri, A. K. Verma and U. Kumar, "Comparison of reliability prediction methods using life cycle cost analysis”, 2013 Proceedings Annual Reliability and Maintainability Symposium (RAMS), Orlando, FL, pp. 17., 2013.

[2] I. Makarova, E.Mukhametdinov, L. Gabsalikhova, R. Garipov, A. Pashkevich, K. Shubenkova,"Justification of the Possibility to Use Vibration Measuring Sensors in Onboard Diagnostic Devices", 2019 International Seminar on Electron Devices Design and Production (SED), 23-24 April 2019, Prague, Czech Republic, Czech Republic, 8798442. DOI: 10.1109/SED.2019.8798442.

[3] T. Tang, Y. Lu, T. Zhou, H. Jing and H. Sun, "FTA and FMEA of braking system based on relex 2009", Proceedings of International Conference on Information Systems for Crisis Response and Management (ISCRAM), Harbin, Heilongjiang, pp. 106-112, 2011

[4] KXu, L.C Tang, MXie, S.LHo, M.LZhu, "Fuzzy assessment of FMEA for engine systems", Reliability Engineering \& System Safety, volume 75, issue 1, pp. 1729, 2002

[5] M. Ślęzak, A. Niewczas, P. Ignaciuk and A. Dmowski, "Comparative analysis of reliability and maintenance costs of heavy goods vehicles of selected brands used under long-term rental", 2018 XI International ScienceTechnical Conference Automotive Safety, Casta, pp. 1-6, 2018.

[6] J. Guo, N. Jiao, L. Jiang, X. Han and X. Zhang, "Hydropneumatic suspension gasbag reliability improvement based on FMEA and FTA", 2014 10th International Conference on Reliability, Maintainability and Safety (ICRMS), Guangzhou, pp. 592-594, 2014.
[7] Sh.Wanga, Y. Liu, C. Di Cairano-Gilfedder, S. Titmus, M. M. Naim, A. A.Syntetos, "Reliability Analysis for Automobile Engines: Conditional Inference Trees", Procedia CIRP, vol. 72, pp. 1392-1397, 2018.

[8] Zh. S. Li, Mohammad S. Mobin, "System reliability assessment incorporating interface and function failure", 2015 Annual Reliability and Maintainability Symposium (RAMS) Publisher: IEEE DOI: 10.1109/RAMS.2015.7105192

[9] X. Wu, Z. Zhu, Sh. Fan,, X. Su, "Failure and reliability prediction of engine systems using iterated nonlinear filters based state-space least square support vector machine method", Optik, volume 127, issue 3, pp. 14911496, 2016.

[10]A. Deptuła, D. Kunderman, P. Osiński, U. Radziwanowska, R. Włostowski, "Acoustic Diagnostics Applications in the Study of Technical Condition of Combustion Engine", Archives of Acoustics, vol. 41, No. 2, pp. 345-350, 2016.

[11] State standard GOST R 41.24-2003 (UNECE Regulation $\mathrm{N} 24$ ). Uniform provisions concerning: I. The approval of compression ignition (C.I.) engines with regard to the emission of visible pollutants; II. The approval of motor vehicles with regard to the installation of C.I. engines of an approved type; III. The approval of motor vehicles equipped with C.I. engines with regard to the emission of visible pollutants by the engine; IV. The measurement of power of engines. URL: http://www.tf.llu.lv/conference/proceedings2016/Papers/ N004.pdf (reference date: June 22, 2020)

[12] State standard ГОСТ P 41.49-2003 (UNECE Regulation N 49). Uniform provisions concerning the certification of compression ignition and natural gas engines as well as positive-ignition engines fueled with liquefied petroleum gas and vehicles equipped with compression ignition and natural gas engines and positive-ignition engines fueled with liquefied petroleum gas, with regard to the emissions of pollutants. URL: http://docs.cntd.ru/document/1200036429 (reference date: June 22, 2020)

Mukhametdinov E.M. PhD in engineering, Associate Professor of the Department "Service of Transport Systems" of the Naberezhnye Chelny Institute (branch), KFU. In 2009 he successfully defended his thesis in the field of 05.22.10 - Operation of road transport "Improving the system of corporate service in order to increase the reliability of vehicles."

Makarova I.V. Doctor in engineering, Professor. Head of the department "Service of Transport Systems" of the Naberezhnye Chelny Institute (branch), KFU. Honorary Worker of Higher Professional Education of the Russian Federation.

Habsalikhova L.M. PhD in engineering, Associate Professor at the Department "Service of Transport Systems" of the Naberezhnye Chelny Institute (branch), KFU. In 2012 she successfully defended her thesis on in the field of 05.22.10 - Operation of road transport "Improvement of planning in the system of corporate service of trucks based on multidimensional analysis."

A.A. Kapitonov. The Head of the Design and Technology Department of Product Design and Technology Quality at "KAMAZ" PJSC.

Khafizullin I.Sh. In 2020 he graduated from the magistracy in the field of 23.04.03 23.04.03 "Operation of transport and technological machines and complexes." Master's program "Car Service and Corporate Service". 